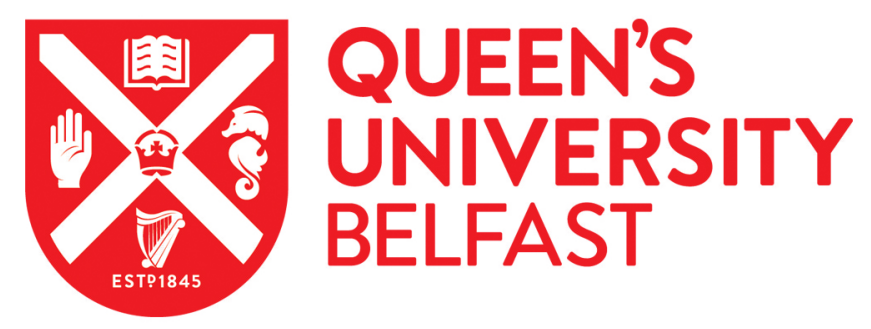

\title{
Mechanism of Catalytic Oxidation of Styrenes with Hydrogen Peroxide in the Presence of Cationic Palladium(II) Complexes
}

Walker, K., Dornan, L., Zare, R., Waymouth, R., \& Muldoon, M. (2017). Mechanism of Catalytic Oxidation of Styrenes with Hydrogen Peroxide in the Presence of Cationic Palladium(II) Complexes. Journal of the American Chemical Society, 139(36), 12495. https://doi.org/10.1021/jacs.7b05413

Published in:

Journal of the American Chemical Society

Document Version:

Peer reviewed version

Queen's University Belfast - Research Portal:

Link to publication record in Queen's University Belfast Research Portal

Publisher rights

Copyright $\odot 2017$ American Chemical Society. This work is made available online in accordance with the publisher's policies. Please refer to any applicable terms of use of the publisher.

\section{General rights}

Copyright for the publications made accessible via the Queen's University Belfast Research Portal is retained by the author(s) and / or other copyright owners and it is a condition of accessing these publications that users recognise and abide by the legal requirements associated with these rights.

Take down policy

The Research Portal is Queen's institutional repository that provides access to Queen's research output. Every effort has been made to ensure that content in the Research Portal does not infringe any person's rights, or applicable UK laws. If you discover content in the Research Portal that you believe breaches copyright or violates any law, please contact openaccess@qub.ac.uk. 


\title{
Mechanism of Catalytic Oxidation of Styrenes with Hydrogen Perox- ide in the Presence of Cationic Palladium(II) Complexes
}

\author{
Katherine L. Walker ${ }^{\dagger}$, Laura M. Dornan ${ }^{\dagger \S}$, Richard N. Zare ${ }^{\dagger}$, Robert M. Waymouth*†, and Mark J. \\ Muldoon*‡ \\ † Department of Chemistry, Stanford University, Stanford, California 94305, United States \\ $\ddagger$ School of Chemistry and Chemical Engineering, Queen’s University Belfast, Northern Ireland, BT9 5AG, United \\ Kingdom
}

$\S$ Both authors contributed equally

\begin{abstract}
Kinetic studies, isotope labeling, and in situ high-resolution mass spectrometry are used to elucidate the mechanism for the catalytic oxidation of styrenes using aqueous hydrogen peroxide $\left(\mathrm{H}_{2} \mathrm{O}_{2}\right)$ and the cationic palladium(II) compound, $\left[(\mathrm{PBO}) \mathrm{Pd}(\mathrm{NCMe})_{2}\right] \mathrm{OTf}_{2}(\mathrm{PBO}=2$-(pyridin-2-yl)benzoxazole $)$. Previous studies have shown that this reaction yields acetophenones with high selectivity. We find that $\mathrm{H}_{2} \mathrm{O}_{2}$ binds to $\mathrm{Pd}(\mathrm{II})$ followed by styrene binding to generate a Pd-alkylperoxide that liberates acetophenone by at least two competitive processes, one of which involves a palladium enolate intermediate that has not been previously observed in olefin oxidation reactions. We suggest that acetophenone is formed from the palladium enolate intermediate by protonation from $\mathrm{H}_{2} \mathrm{O}_{2}$. We replaced hydrogen peroxide with $t$-butyl hydroperoxide and found that although the palladium enolate intermediate was observed, it was not on the major product-generating pathway, indicating that the form of the oxidant plays a key role in the reaction mechanism.
\end{abstract}

\section{INTRODUCTION}

The catalytic oxidation of alkenes provides an expedient synthesis of carbonyl compounds. Despite recent advances, ${ }^{1-3}$ many challenges remain. The Wacker Process for aerobic oxidation of ethylene to acetaldehyde with palladium chloride / copper chloride is a textbook example of industrial oxidation of an alkene; ${ }^{4}$ however, this catalyst system is typically less effective for alkenes other than ethylene..$^{5-6}$ Efforts to replace the copper salts with other electron-transfer mediators to facilitate the re-oxidation of $\operatorname{Pd}(0)$ have met with some success, ${ }^{7-24}$ as have efforts to employ alternative oxidants. ${ }^{25-28}$

Direct aerobic oxidations of alkenes in the absence of mediators are also known, ${ }^{29-38}$ but for the oxidation of styrenes, ${ }^{33-34}$ these systems typically require high loadings of Pd catalyst (5$10 \mathrm{~mol} \%$ ) and lengthy reaction times. The Muldoon group recently reported an efficient catalytic oxidation of styrenes with hydrogen peroxide $\left(\mathrm{H}_{2} \mathrm{O}_{2}\right)$ in the presence of cationic Pd complexes ligated with 2-(pyridin-2-yl)benzoxazole (PBO), $\left[(\mathrm{PBO}) \mathrm{Pd}(\mathrm{NCMe})_{2}\right][\mathrm{OTf}]_{2},(\mathbf{A}$, Scheme 1$) .{ }^{39}$ While this catalyst is selective for styrenyl substrates, aliphatic terminal alkenes are isomerized rapidly and give low yields of their corresponding 2-ketones. ${ }^{39}$ Internal alkenes do not undergo oxidation under these conditions.

Hydrogen peroxide is an attractive oxidant $;^{40}$ it is inexpensive, degrades only to $\mathrm{O}_{2}$ and $\mathrm{H}_{2} \mathrm{O}$, and has been utilized industrially for the production of pharmaceuticals ${ }^{41}$ as well as large scale commodity chemicals such as propylene oxide. ${ }^{42}$ While the use of aqueous $\mathrm{H}_{2} \mathrm{O}_{2}$ for Wacker-type oxidations dates to the $1960 \mathrm{~s},{ }^{43}$ considerably less is known regarding the mechanism of alkene oxidations mediated by $\mathrm{H}_{2} \mathrm{O}_{2}{ }^{44-45}$ relative to those employing $\mathrm{O}_{2},{ }^{46-49}$ or alkyl hydroperoxides. ${ }^{50-54}$ Herein we describe kinetic investigations, isotope labeling studies and insitu high-resolution mass spectrometry ${ }^{55-57}$ of $\mathrm{Pd}(\mathrm{II}) / \mathrm{H}_{2} \mathrm{O}_{2}$ catalyzed oxidation of styrenes. These studies provide clear evidence for a mechanism involving the initial formation of a Pd hydroperoxide intermediate ${ }^{50,54}$ which reacts with styrene to generate a Pd-alkylperoxide intermediate that liberates acetophenone by at least two competitive processes, one of which involves an unusual palladium enolate intermediate (Scheme 1).

Scheme 1. Oxidation of styrene with $\mathrm{H}_{2} \mathrm{O}_{2}{ }^{39}$

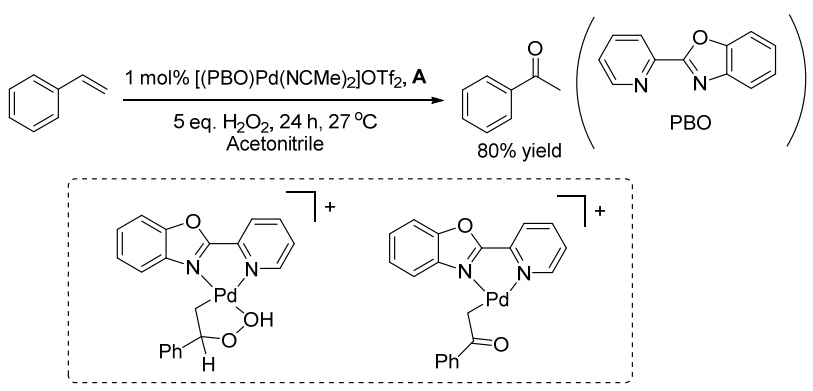

RESULTS

Kinetic Studies. The catalytic oxidation of styrene with $\mathrm{H}_{2} \mathrm{O}_{2}$ ( 5 eq. relative to styrene) in ambient air in the presence of $\left[(\mathrm{PBO}) \mathrm{Pd}(\mathrm{NCMe})_{2}\right][\mathrm{OTf}]_{2}, \mathbf{A}$, affords acetophenone in $80 \%$ yield after $24 \mathrm{~h}$ (Scheme 1). ${ }^{39}$ The kinetics were analyzed by 
monitoring the concentrations as a function of time by gas chromatography. The initial rates were determined by monitoring the concentration of styrene up to $10-15 \%$ conversion. These experiments reveal that the initial rates exhibited a linear dependence on both [styrene] and [Pd] (Figure 1).

A

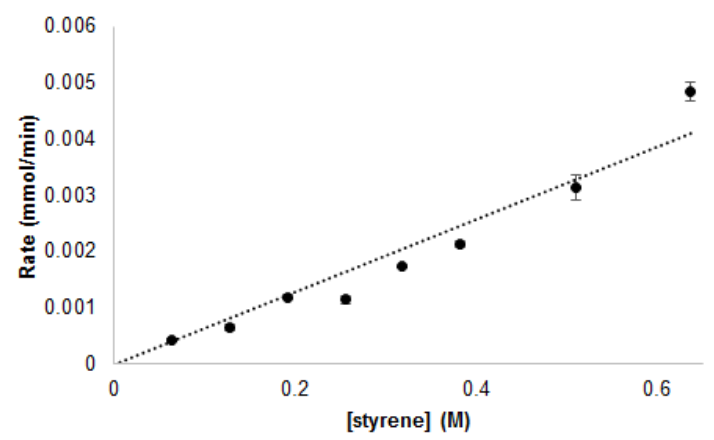

B

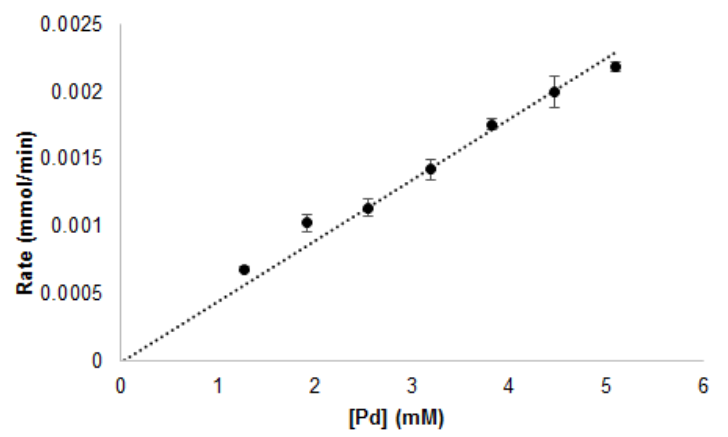

Figure 1. Initial rates for the oxidation of styrene by $\mathbf{A}$ with $\mathrm{H}_{2} \mathrm{O}_{2}$. (A) Initial rates vs. [styrene] (Conditions: $2.55 \mathrm{mM} \mathrm{A}, 1.275$ $\mathrm{M} \mathrm{H}_{2} \mathrm{O}_{2}, 2.534 \mathrm{M} \mathrm{H}_{2} \mathrm{O}, \mathrm{MeCN}$, total volume $4.33 \mathrm{~mL}$ ) (B) Initial rates vs. [Pd]. (Conditions: $0.255 \mathrm{M}$ styrene, $1.275 \mathrm{M} \mathrm{H}_{2} \mathrm{O}_{2}, 2.534$ $\mathrm{M} \mathrm{H}_{2} \mathrm{O}, \mathrm{MeCN}$, total volume $4.33 \mathrm{~mL}$ ). Error bars represent one standard deviation for three replicate runs.

The initial rates exhibited saturation behavior with the concentration of hydrogen peroxide; for $\left[\mathrm{H}_{2} \mathrm{O}_{2}\right] \leq 0.3 \mathrm{M}$ (approximately 1.2 equivalents of $\mathrm{H}_{2} \mathrm{O}_{2}$ relative to styrene) the rate increases linearly with $\left[\mathrm{H}_{2} \mathrm{O}_{2}\right]$, after which the rate is independent of peroxide concentration (Figure 2). The initial rates exhibited a similar saturation behavior with the concentration of water, exhibiting a linear increase in rate for $\left[\mathrm{H}_{2} \mathrm{O}\right] \leq 2.5 \mathrm{M}$, but the initial rates do not change significantly at higher $\left[\mathrm{H}_{2} \mathrm{O}\right]$. Control experiments reveal that oxidation of styrene under similar conditions in the absence of $\mathrm{H}_{2} \mathrm{O}_{2}$ affords a $24 \%$ yield of acetophenone (Scheme 2), ${ }^{39}$ indicating that aerobic Wacker oxidation of styrene can also occur under these conditions and may be responsible for some fraction of the acetophenone generated, even in the presence of $\mathrm{H}_{2} \mathrm{O}_{2}$.

The initial rates for a range of substituted styrenes were investigated to probe the influence of electronic effects on the rate of styrene oxidation (Figure 3). These data revealed a linear free energy relationship between the logarithm of the rate vs. the Hammett $\sigma$ parameter. This plot yields a negative slope with $\rho=-1.61$, indicating slower rates for more electron-deficient styrenes.
A
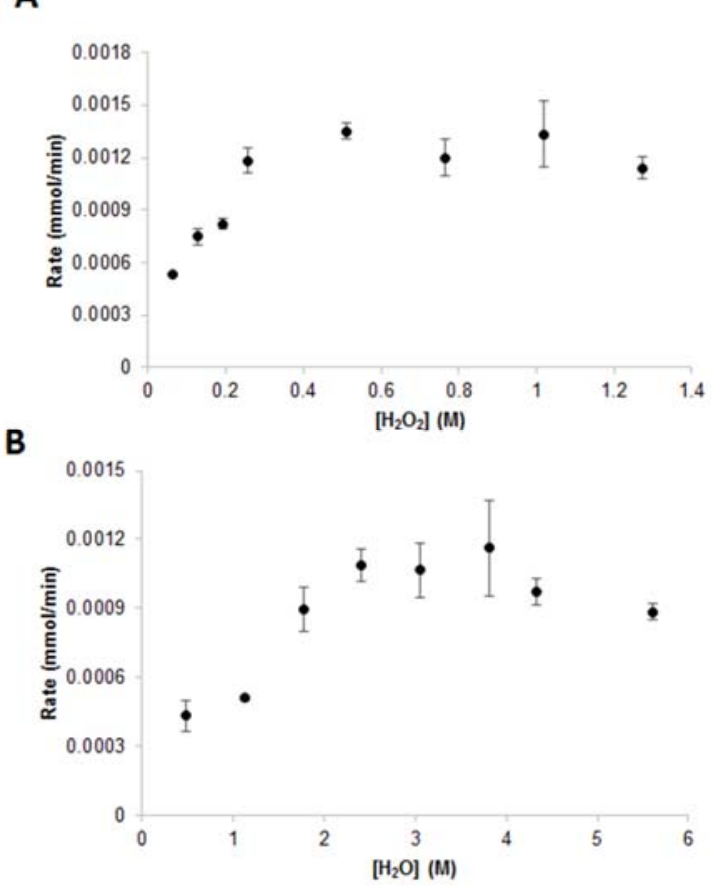

Figure 2. Initial rates for the oxidation of styrene by $\mathbf{A}$ as a function of $\left[\mathrm{H}_{2} \mathrm{O}_{2}\right]$ and $\left[\mathrm{H}_{2} \mathrm{O}\right]$. (A) Conditions: $0.255 \mathrm{M}$ styrene, 2.55 $\mathrm{mM} \mathrm{A}, 2.534 \mathrm{M} \mathrm{H}_{2} \mathrm{O}, \mathrm{MeCN}$, total volume $4.33 \mathrm{~mL}$, (B) Conditions: $0.255 \mathrm{M}$ styrene, $2.55 \mathrm{mM} \mathrm{A}, 1.275 \mathrm{M} \mathrm{H}_{2} \mathrm{O}_{2}, \mathrm{MeCN}$, total volume $4.33 \mathrm{~mL}$. Error bars represent one standard deviation for three replicate runs.

\section{Scheme 2. Product formation via aerobic Wacker oxida-} tion
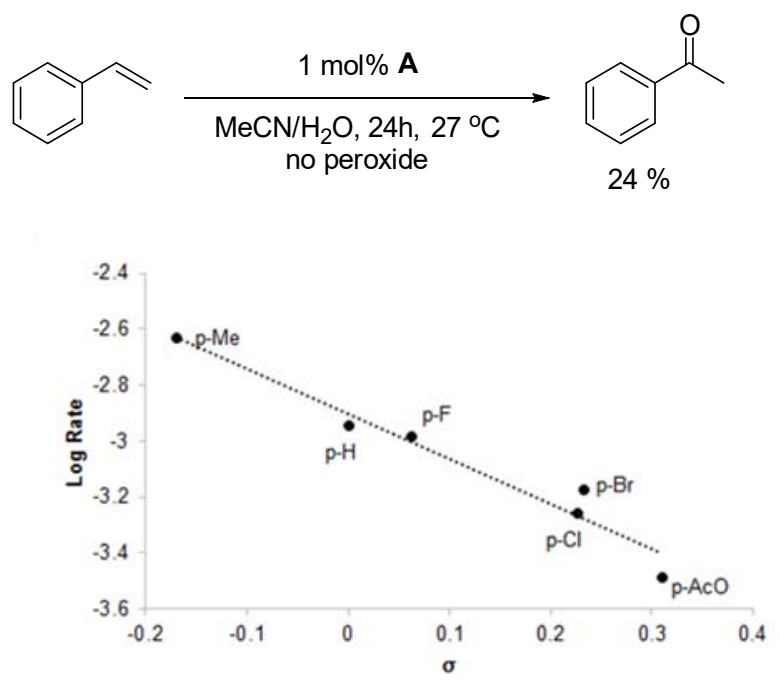

Figure 3. Hammett plot for substituted styrenes. (Conditions: $0.255 \mathrm{M}$ styrene, $2.55 \mathrm{mM} \mathrm{A}, 2.534 \mathrm{M} \mathrm{H}_{2} \mathrm{O}, 1.275 \mathrm{M} \mathrm{H}_{2} \mathrm{O}_{2} \mathrm{MeCN}$, total volume $4.33 \mathrm{~mL}$ ) 
Mass Spectrometry and Isotope Labeling. To provide insight on the nature of catalytic intermediates and the speciation of Pd species during the catalytic reaction, we utilized high-resolution electrospray mass spectrometry (ESI-MS), combined with isotope-labeling studies to monitor the catalytic oxidation of styrene with $\left[(\mathrm{PBO}) \mathrm{Pd}(\mathrm{NCMe})_{2}\right][\mathrm{OTf}]_{2}$, A. Analysis of catalytic reactions by ESI-MS techniques coupled with other mechanistic tools and kinetic studies can provide valuable insights into complex catalytic mechanisms. ${ }^{48,55,58-61}$ We have recently used ESI-MS to investigate the mechanisms of aerobic Pd(II) catalysis for alcohol oxidation ${ }^{56,62}$ and $\mathrm{H}_{2} \mathrm{O}_{2}$ disproportionation. ${ }^{57}$

Oxidations of $0.2 \mathrm{M}$ styrene in ambient air with $1 \mathrm{M} \mathrm{H}_{2} \mathrm{O}_{2}$ in the presence of $2 \mathrm{mM} \mathrm{A}$ in $\mathrm{MeCN} / \mathrm{H}_{2} \mathrm{O}$ were investigated by taking aliquots and diluting them directly before analyzing the reaction mixture by ESI-MS (Scheme 3). Immediately, an envelope of peaks centered at $334.9656 \mathrm{~m} / \mathrm{z}$ is observed at reaction times as short as one minute - corresponding to the Pd hydroperoxide species $[(\mathrm{PBO}) \mathrm{Pd}-\mathrm{OOH}]^{+},[\mathbf{B}]^{+}$. This ion appears early in the reaction and is observed throughout the reaction. At early reaction times, another envelope of peaks is evident at $469.4429 \mathrm{~m} / \mathrm{z}$, but is not present after tens of minutes and later reaction times. This ion is formulated as the trimeric $\left[\mathrm{PBO}_{3} \mathrm{Pd}_{3} \mathrm{O}_{2}\right]^{2+}$, an ion analogous to that observed and characterized in $\mathrm{O}_{2}$ or $\mathrm{H}_{2} \mathrm{O}_{2}$ mediated oxidations with cationic Pd neocuproine complexes. ${ }^{56-57}$

After one hour of reaction, the major observed species is an ion at $421.0151 \mathrm{~m} / \mathrm{z}$, corresponding to the formula [PBOPd$\left.\mathrm{CH}_{2} \mathrm{COPh}\right]^{+},[\mathbf{C}]^{+}$which we assign as a Pd-enolate. ${ }^{63}$ This ion remains the dominant species throughout the reaction. This was an unexpected observation as such a species has rarely been observed or postulated in Wacker-type reactions of styrene. To more fully characterize this ion, collision induced dissociation (CID) mass spectrometry was carried out and revealed daughter ions that have lost either $\mathrm{CO}$ or $\mathrm{CH}_{2} \mathrm{CO}$, which agrees with a Pd-enolate ion. ${ }^{63}$ ESI-MS of analogous reactions using 4fluorostyrene and 3-nitrostyrene gave ions at $439.0050 \mathrm{~m} / \mathrm{z}$ and $465.9990 \mathrm{~m} / \mathrm{z}$, respectively, consistent with corresponding palladium enolates. When the product acetophenone was subjected to the typical catalytic conditions in the absence of styrene, no ions corresponding to the Pd enolate could be observed, implying that these ions are not derived from acetophenone.

Attempts to independently prepare the proposed $\left[\mathrm{PBOPd}\left(\mathrm{CH}_{2} \mathrm{COPh}\right)\right] \mathrm{OTf}$ were unsuccessful. However, the analogous 1,10-phenanthroline (phen) complex, $\left[(\right.$ phen $\left.) \mathrm{Pd}\left(\mathrm{CH}_{2} \mathrm{COPh}\right)(\mathrm{NCMe})\right][\mathrm{OTf}]$, (phen-C), was successfully synthesized and characterized. The ${ }^{1} \mathrm{H}$ and ${ }^{13} \mathrm{C}$ NMR spectra of this compound are consistent with its formulation as a Cbound enolate. ${ }^{63}$ The ESI-MS of phen-C afforded an envelope of ions centered at $405.0219 \mathrm{~m} / \mathrm{z}$ corresponding to $\left[(\text { phen }) \mathrm{Pd}\left(\mathrm{CH}_{2} \mathrm{COPh}\right)\right]^{+}$; furthermore the CID spectrum had the same pattern of daughter peaks as those observed from $[\mathbf{C}]^{+}$, providing indirect evidence that the enolate $[\mathbf{C}]^{+}$is $\mathrm{C}$-bound and not O-bound. ${ }^{63}$ Treatment of a $\mathrm{CD}_{3} \mathrm{CN}$ solution of this enolate with $1 \mathrm{M} \mathrm{D}_{2} \mathrm{O}_{2}$ afforded acetophenone in $5 \%$ yield, $91 \%$ of which was $\mathrm{d}_{1}$-acetophenone. When an analogous reaction was carried out with $\mathrm{H}_{2} \mathrm{O}_{2}$ and analyzed by ESI-MS, the ion corre- sponding to $[(\text { phen }) \mathrm{Pd}-\mathrm{OOH}]^{+}$was observed; these results indicate that the C-bound enolates can be protonated by $\mathrm{H}_{2} \mathrm{O}_{2}$ to afford acetophenone, although this process is not very efficient with the phen ligand (phen had been previously shown to be a poor ligand for the catalytic oxidation of styrene. ${ }^{39}$ )

Scheme 3. Ions observed from ESI-MS

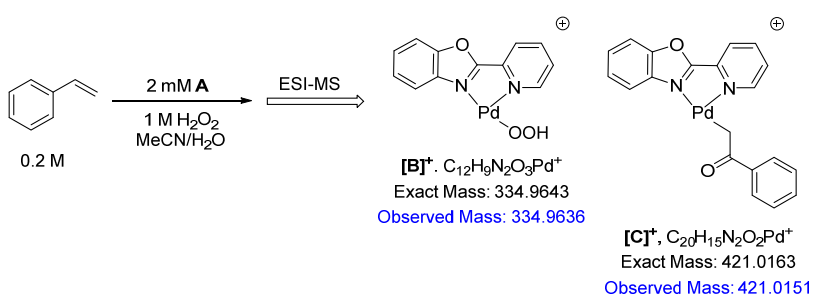

To provide further information on the processes that lead to the Pd enolate ion and its role in the oxidation reaction, a series of isotope labeling studies were carried out. The catalytic oxidation of $0.2 \mathrm{M}$ styrene with $1 \mathrm{M} \mathrm{D}_{2} \mathrm{O}_{2}$ (approx. $98 \%$ D-labeled) in $\mathrm{MeCN} / \mathrm{D}_{2} \mathrm{O}$ catalyzed by $2 \mathrm{mM} \mathrm{A}$, afforded a mixture of $\mathrm{d}_{1-}$ acetophenone $(67 \%)$ and acetophenone $(33 \%)$ (Scheme $4 a)$. Kinetic experiments revealed a primary kinetic isotope effect of $\mathrm{k}_{\mathrm{H}} / \mathrm{k}_{\mathrm{D}}\left(\mathrm{H}_{2} \mathrm{O}_{2} / \mathrm{D}_{2} \mathrm{O}_{2}\right)=1.92$. A control experiment under the same $\mathrm{D}_{2} \mathrm{O}_{2}$ conditions with acetophenone instead of styrene yielded no $d_{1}$-acetophenone, indicating that $d_{1}$-acetophenone is not derived from the product acetophenone. When this control reaction with acetophenone was monitored by ESI-MS, two overlapping ion envelopes centered at $334.9656 \mathrm{~m} / \mathrm{z}$ and 335.9700 $\mathrm{m} / \mathrm{z}$ were observed, corresponding to a mixture of $[\mathbf{B}]^{+}$and $[\mathrm{PBOPd}-\mathrm{OOD}]^{+},\left[\mathbf{d}_{\mathbf{1}}-\mathbf{B}\right]^{+}$. However, the ion corresponding to the Pd-enolate was observed at $421.0179 \mathrm{~m} / \mathrm{z}$, indicating that the enolate generated under these conditions contains no deuterium. These observations suggest that $d_{1}$-acetophenone likely arises from deuterolysis of the $\mathrm{C}$-bound Pd-enolate.

Catalytic oxidation of $0.2 \mathrm{M} \alpha$-D-styrene with $1 \mathrm{M} \mathrm{H}_{2} \mathrm{O}_{2}$ and $2 \mathrm{mM}$ [A] in $\mathrm{MeCN} / \mathrm{H}_{2} \mathrm{O}$ leads to a mixture of $\mathrm{d}_{1}$-acetophenone $(30 \%)$ and unlabeled acetophenone (70\%) (Scheme 4b). Kinetic studies revealed a negligible kinetic isotope effect $\mathrm{k}_{\mathrm{H}} / \mathrm{k}_{\mathrm{D}}=$ 0.97 (styrene vs. $\alpha$-D-styrene). In contrast, when the oxidation of $\alpha$-D-styrene was carried out in $\mathrm{D}_{2} \mathrm{O}_{2} / \mathrm{D}_{2} \mathrm{O}$, over $92 \%$ of the acetophenone was deuteriated (Scheme $4 \mathrm{~b}$ ). When this reaction was monitored by ESI-MS, the undeuteriated enolate $[\mathbf{C}]^{+}$was observed, indicating that the Pd-enolate derived from $\alpha$-D-styrene lost its deuterium atom.

When the catalytic oxidation of $20 \mathrm{mM}$ styrene with $2 \mathrm{mM} \mathbf{A}$ was carried out with ${ }^{18} \mathrm{O}$-labeled hydrogen peroxide $(0.1 \mathrm{M}$ $\mathrm{H}_{2}{ }^{18} \mathrm{O}_{2}$ ) in $\mathrm{MeCN} / \mathrm{H}_{2} \mathrm{O}$, GCMS analysis revealed that $74 \%$ of the acetophenone product is ${ }^{18} \mathrm{O}$ labeled (Scheme 4c). The ESIMS of this reaction revealed ions at $338.9739 \mathrm{~m} / \mathrm{z}$ corresponding to the palladium hydroperoxide containing two ${ }^{18} \mathrm{O}$ atoms, $\left[{ }^{18} \mathrm{O}_{2}-\mathbf{B}\right]^{+}$. The ion corresponding to the palladium enolate shifts to $423.0211 \mathrm{~m} / \mathrm{z},\left[{ }^{18} \mathbf{O}-\mathbf{C}\right]^{+}$, which indicates that the oxygen in the enolate is derived from the labeled hydrogen peroxide. When an analogous experiment was carried out with unlabeled $\mathrm{H}_{2} \mathrm{O}_{2}$ in labeled $\mathrm{H}_{2}{ }^{18} \mathrm{O}$ water, the ion corresponding to the $\mathrm{Pd}$ enolate did not incorporate the ${ }^{18} \mathrm{O}$ from water (see Supporting Information). 
Scheme 4. Isotope-labeling studies

(a)
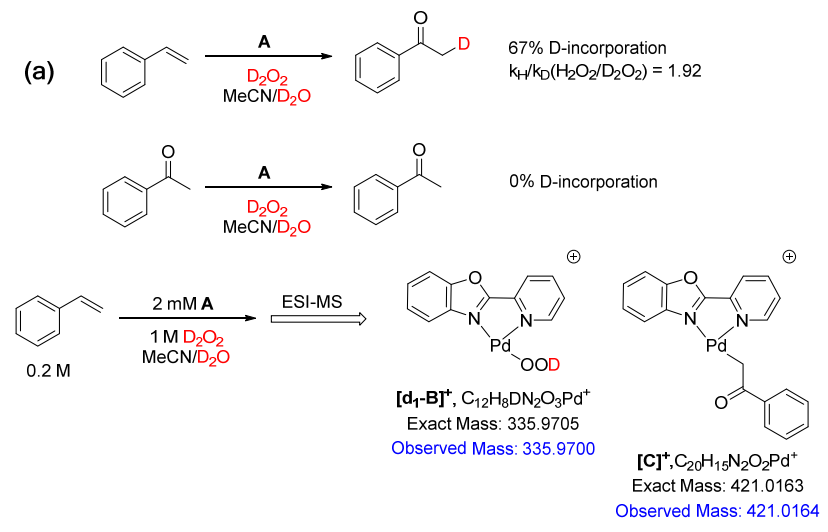

(b)

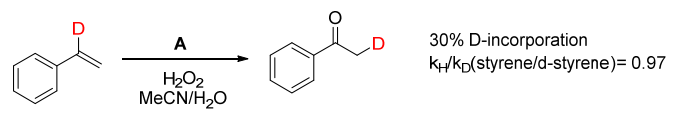

92\% D-incorporation

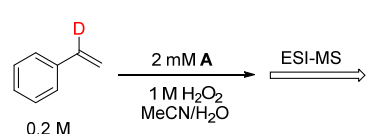

$0.2 \mathrm{M}$

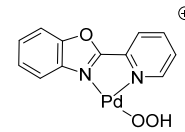

$[\mathrm{B}]^{+}, \mathrm{C}_{12} \mathrm{H}_{9} \mathrm{~N}_{2} \mathrm{O}_{3} \mathrm{Pd}^{+}$ Exact Mass: 334.9643 Observed Mass: 334.9666

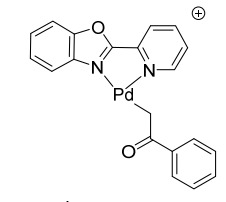

$[\mathrm{C}]^{+}, \mathrm{C}_{20} \mathrm{H}_{15} \mathrm{~N}_{2} \mathrm{O}_{2} \mathrm{Pd}^{+}$ Exact Mass: 421.0163 Observed Mass: 421.0195

(c)
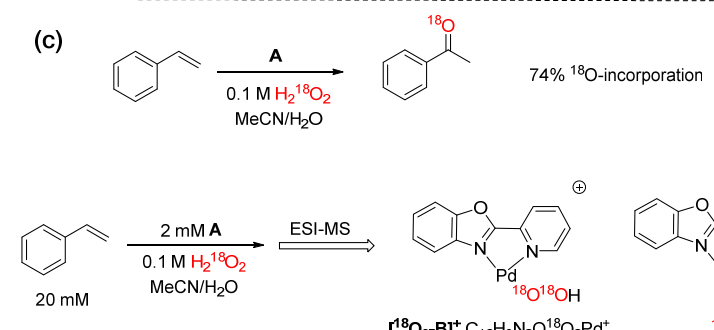

$\left[{ }^{18} \mathrm{O}_{2}-\mathrm{B}\right]^{+}, \mathrm{C}_{12} \mathrm{H}_{9} \mathrm{~N}_{2} \mathrm{O}^{18} \mathrm{O}_{2} \mathrm{Pd}^{+}$

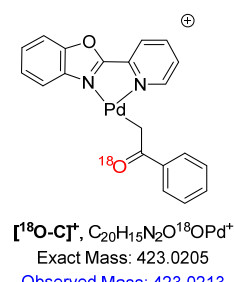

Scheme 5. Ions observed from ESI-MS with CHD additive
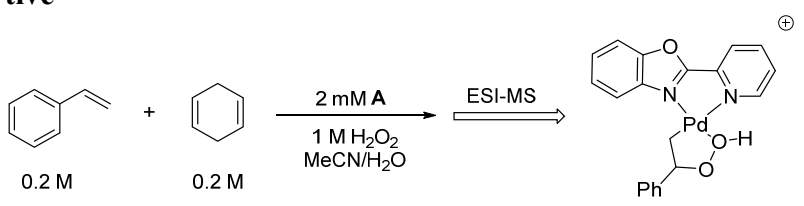

$[\mathrm{D}]^{+}, \mathrm{C}_{20} \mathrm{H}_{17} \mathrm{~N}_{2} \mathrm{O}_{3} \mathrm{Pd}^{+}$

Exact Mass: 439.0269

Observed Mass: 439.0274

Efforts to investigate the influence of radical traps or hydrogen atom donors on the oxidation of styrene with $\mathrm{H}_{2} \mathrm{O}_{2}$ were ambiguous. Addition of TEMPO or TEMPOH (TEMPO $=$ (2,2,6,6-Tetramethylpiperidin-1-yl)oxyl) completely shut down the reaction, and were thus not informative. The addition of one equivalent (relative to styrene) of 1,4-cyclohexadiene (CHD) to a styrene oxidation reaction with $\mathrm{H}_{2} \mathrm{O}_{2}$ resulted in a decrease in rate, but exhibited a similar selectivity to those carried out with $\mathrm{D}_{2} \mathrm{O}_{2}$ or $\alpha$-D-styrene in the absence of CHD. We were encouraged to look at this reaction by ESI-MS to assess if the lower rates observed in the presence of CHD might enable observation of short-lived intermediates that might not otherwise be detectable. Analysis of the reaction of $0.2 \mathrm{M}$ styrene and $2 \mathrm{M} \mathrm{H}_{2} \mathrm{O}_{2}$ in MeCN catalyzed by $2 \mathrm{mM} \mathrm{A}$ in the presence of $0.2 \mathrm{M} \mathrm{CHD}$ revealed an envelope of ions at $439.0274 \mathrm{~m} / \mathrm{z}$ in low relative abundance at early time points (Scheme 5). This ion corresponds to the formula $\left.\left[\mathrm{PBOPdCH} \mathrm{PH}_{2} \mathrm{CH}(\mathrm{OOH}) \mathrm{Ph}\right)\right]^{+},[\mathbf{D}]^{+}$, corresponding to a Pd alkylperoxide, an intermediate which had been previously proposed by Mimoun ${ }^{44,50}$ and $\operatorname{Sigman}^{51,54}$ in peroxide-mediated oxidations of olefins. Other intermediates with CHD coordinated to the Pd center were also observed (see Supporting Information).

In an effort to identify short-lived intermediates, alternative electrospray techniques were employed. Desorption electrospray ionization (DESI) MS is a useful technique for observing species that form on the microsecond time scale. ${ }^{64-65}$ For these experiments, an acetonitrile solution of the Pd precursor A was deposited on a porous Teflon sheet and allowed to dry. A solution of styrene and $\mathrm{H}_{2} \mathrm{O}_{2}$ in $\mathrm{MeCN}$ was then sprayed onto it using an ESI source, and the secondary microdroplets generated were analyzed by MS. One of the first ions observed was the $\mathrm{Pd}-\mathrm{OOH}$ ion $[\mathbf{B}]^{+}$; subsequently, ions corresponding to the $\mathrm{Pd}$-enolate $[\mathbf{C}]^{+}$grew in slowly over about a minute. These experiments suggest that the hydroperoxide $[\mathbf{B}]^{+}$is formed rapidly upon contact of hydrogen peroxide with the cationic Pd precursor A. These experiments were corroborated utilizing a theta capillary nanoESI experiment. In this technique, two solutions are simultaneously sprayed from two barrels of a single capillary with a $\sim 2 \mu \mathrm{m}$ tip, resulting in mixing just prior to formation of the primary droplets. Depending on the distance of the spray from the mass spectrometer, this technique results in mixing times on the order of $10-1000 \mu \mathrm{s} .{ }^{66-68}$ When separate $\mathrm{MeCN}$ solutions of $\mathbf{A}$ and styrene mixed with $\mathrm{H}_{2} \mathrm{O}_{2}$ were sprayed through the theta capillary, the predominant ion observed (other than the precursor $\left.\left[(\mathrm{PBO}) \mathrm{Pd}(\mathrm{NCMe})_{2}\right]^{2+}\right)$ was that corresponding to $[B]^{+}$. Ions corresponding to the palladium enolate were not observed under these conditions, from which we conclude that the Pd hydroperoxide is formed prior to the Pd enolate.

Aerobic Wacker Oxidation. As prior studies ${ }^{39}$ had suggested that some fraction of the acetophenone that is produced when styrene is oxidized with $\mathrm{H}_{2} \mathrm{O}_{2}$ in air may derive from a competitive aerobic Wacker reaction (Scheme 2, 24\% after 24 $\mathrm{h}$ in air vs. $80 \%$ with $\mathrm{H}_{2} \mathrm{O}_{2}$ ), we carried out several experiments to monitor the oxidation of styrene in air in the absence of hydrogen peroxide (Scheme 6). When 0.2 M styrene was oxidized in air in $4 \mathrm{M} \mathrm{D}_{2} \mathrm{O}$ (in $\mathrm{MeCN}$ ) with $2 \mathrm{mM} \mathrm{A}$, analysis of the resulting acetophenone revealed undetectable amounts of deuterium incorporation. In contrast, for $\alpha$-D-styrene under similar conditions, $82 \%$ of the acetophenone was labeled.

Scheme 6. Aerobic Wacker isotope labeling studies 


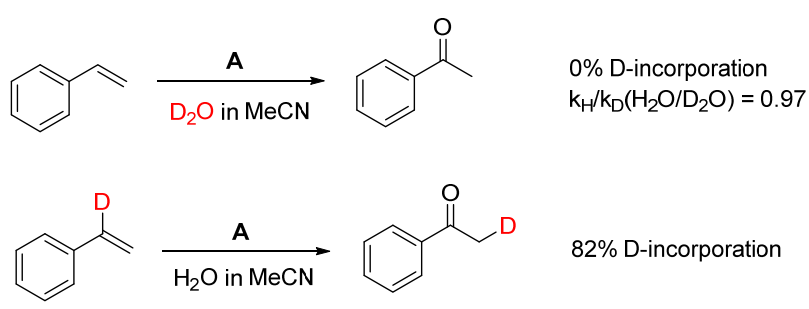

When these reactions were analyzed by ESI-MS, at early reaction time points, the mass spectrum was similar to that of $\left[(\mathrm{PBO}) \mathrm{Pd}(\mathrm{NCMe})_{2}\right] \mathrm{OTf}_{2}$ in wet $\mathrm{MeCN}$. However, after one hour, the peak at $421.0179 \mathrm{~m} / \mathrm{z}$ (corresponding to Pd-enolate) began to grow in, albeit in a much lower relative abundance than observed in the presence of $\mathrm{H}_{2} \mathrm{O}_{2}$. This peak was also present when $\mathrm{D}_{2} \mathrm{O}$ was used instead of $\mathrm{H}_{2} \mathrm{O}$.

Other Peroxide Oxidants. The observation of the Pd-enolate intermediate was unexpected, as this intermediate had not been commonly invoked in Wacker-type oxidations. ${ }^{1}$ To assess the generality of this observation and the potential role of Pdenolates in other olefin oxidation reactions, we investigated the oxidation of styrene with t-butyl hydroperoxide (TBHP) under conditions analogous to those reported by Sigman. ${ }^{52,54}$

When the catalytic oxidation of $\alpha$-D-styrene with (Quinox) $\mathrm{PdCl}_{2} / \mathrm{AgSbF}_{6}$ (Quinox = 2-(4,5-dihydro-2-oxazolyl)quinolone) was carried out in $\mathrm{CH}_{2} \mathrm{Cl}_{2}$ with TBHP $(70 \%$ solution in water), analysis of the reaction mixture revealed that $98 \%$ of acetophenone generated was mono-deuteriated.

\section{Scheme 7. Ions observed from ESI-MS for the Quinox/TBHP System}

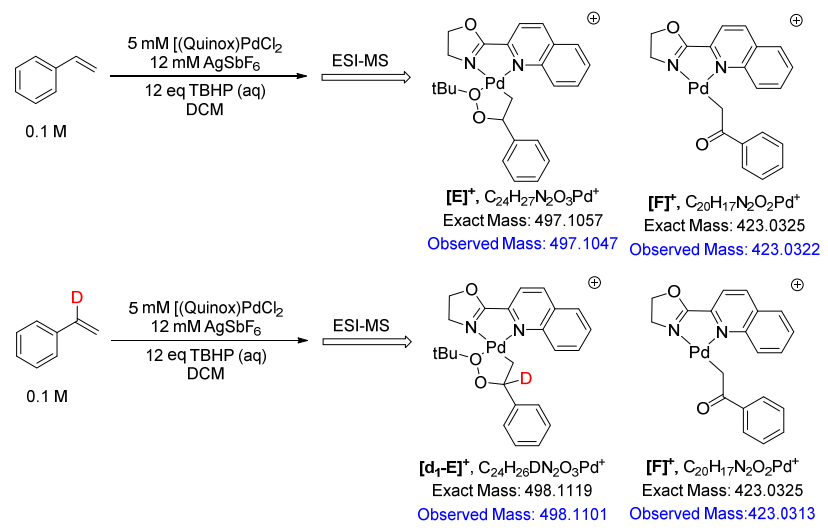

When the oxidation of styrene with TBHP was monitored by ESI-MS, two major species were observed after 15 minutes: an ion at $497.1047 \mathrm{~m} / \mathrm{z}$ and one at $423.0422 \mathrm{~m} / \mathrm{z}$ (see Supporting Information). The former corresponds to the formula $\left[(\right.$ Quinox $\left.\left.) \mathrm{Pd}-\mathrm{CH}_{2} \mathrm{CH}(\mathrm{OOtBu}) \mathrm{Ph}\right)\right]^{+},[\mathbf{E}]^{+}$, and the latter to $\left[(\right.$ Quinox $\left.\left.) \mathrm{Pd}-\mathrm{CH}_{2} \mathrm{COPh}\right)\right]^{+},[\mathbf{F}]^{+}$(Scheme 7). The CID spectrum of $[\mathbf{E}]^{+}$(Figure S42) shows, instead of loss of styrene, fragmentation peaks consistent with $\mathrm{O}-\mathrm{O}$ bond cleavage to produce $[\mathbf{F}]^{+}$ as well as loss of the t-butyl group. This fragmentation pattern is most consistent with a palladium alkylperoxide, rather than a palladium peroxide with a coordinated styrene. When the same reaction was carried out with $\alpha$-D-styrene, analysis of the mass spectra revealed ions corresponding to the Pd alkylperoxide $\left[(\right.$ Quinox $\left.\left.) \mathrm{Pd}-\mathrm{CH}_{2} \mathrm{CD}(\mathrm{OOtBu}) \mathrm{Ph}\right)\right]^{+}, \quad\left[\mathbf{d}_{\mathbf{1}}-\mathbf{E}\right]^{+}$, containing one deuterium; in contrast, the ion corresponding to the Pd-enolate did not contain a deuterium label. Both $\operatorname{Sigman}^{54}$ and Mimoun ${ }^{44}$ had proposed that alkylperoxides are key intermediates in the peroxide-mediated oxidations of olefins. The results of the insitu mass spectroscopy measurements are fully consistent with this hypothesis.

\section{Scheme 8. PBOPd with TBHP deuterium labeling}

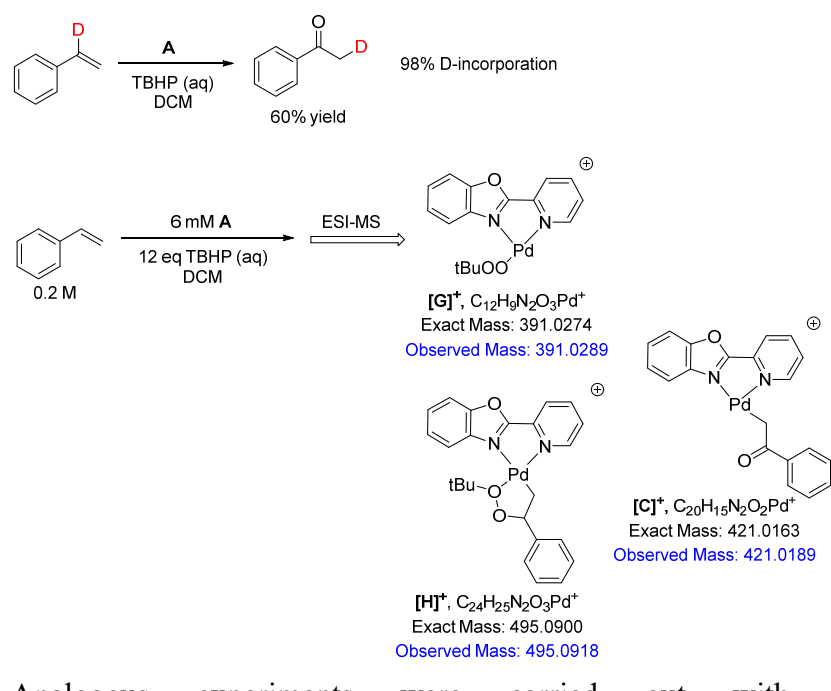

Analogous experiments were carried out with $\left[(\mathrm{PBO}) \mathrm{Pd}(\mathrm{NCMe})_{2}\right][\mathrm{OTf}]_{2}, \mathbf{A}$, in an effort to assess both the role of the ligand and oxidant on the distribution of deuterium in the products. Oxidation of $\alpha$-D-styrene with TBHP in the presence of $\mathbf{A}$ afforded 60\% yield of acetophenone after 1 hour where $98 \%$ of the acetophenone was deuteriated (Scheme 8). Analysis of a reaction with perprotio styrene by ESI-MS revealed ions corresponding to the Pd-tertbutylperoxide, $[\mathbf{G}]^{+}$ $(391.0289 \mathrm{~m} / \mathrm{z})$, the Pd alkylperoxide, $[\mathbf{H}]^{+}(495.0918 \mathrm{~m} / \mathrm{z})$ and the Pd-enolate, $[\mathbf{C}]^{+}(421.0189 \mathrm{~m} / \mathrm{z})$.

These latter experiments are informative, as they clearly indicate that with the same ligand system (PBO), the nature of the oxidant has a significant influence on the fate of the deuterium derived from $\alpha$-D-styrene and on the observed intermediates by ESI-MS. When $\mathrm{H}_{2} \mathrm{O}_{2}$ is used as the oxidant, only $30 \%$ of the resulting acetophenone is labeled with deuterium, whereas when TBHP is the oxidant, $98 \%$ of the acetophenone is labeled.

\section{DISCUSSION}

The results of this study indicate that the catalytic oxidation of styrene with $\left[(\mathrm{PBO}) \mathrm{Pd}(\mathrm{NCMe})_{2}\right][\mathrm{OTf}]_{2}, \mathbf{A}$, and $\mathrm{H}_{2} \mathrm{O}_{2}$ as the terminal oxidant proceeds by several competitive pathways (Scheme 9, represented with $\alpha$-D styrene), including a competitive oxidation pathway mediated by $\mathrm{O}_{2}$ (aerobic Wacker reaction). In the following, we will describe the cumulative evidence obtained from kinetic measurements, isotope labeling, and in-situ mass spectrometry that are consistent with this proposal.

Experimental data from DESI and theta capillary nanoESI provide compelling evidence that the initial intermediate formed within microseconds upon reaction of $\mathbf{A}$ with $\mathrm{H}_{2} \mathrm{O}_{2}$ is 
the Pd-OOH intermediate B. Mimoun ${ }^{44,50}$ and others ${ }^{69-70}$ had previously proposed the formation of a Pd-OOR intermediate as a first step in olefin oxidation reactions by hydrogen peroxide or alkyl hydroperoxides. ${ }^{51,54}$ This hypothesis that intermediate $\mathbf{B}$ is the first step of the mechanism is also supported by the first order kinetics observed with [Pd], saturation-type kinetics observed with $\mathrm{H}_{2} \mathrm{O}_{2}$ and the kinetic isotope effect $\left(\mathrm{H}_{2} \mathrm{O}_{2} / \mathrm{D}_{2} \mathrm{O}_{2}\right)$ of 1.92. Pd-hydroperoxide species can be generated from aerobic pathways, either from the direct reaction of molecular oxygen with Pd-H species, or via protonation of Pd peroxo species. ${ }^{1,71-}$ ${ }^{75}$ The use of labeled $\mathrm{H}_{2}{ }^{18} \mathrm{O}_{2}$ and the observation of subsequent ${ }^{18} \mathrm{O}$-incorporation in $\mathrm{Pd}-\mathrm{OOH}(\mathrm{B})$ is strong evidence that this $\mathrm{Pd}$-hydroperoxide is the result of direct reaction of the Pd catalyst with $\mathrm{H}_{2} \mathrm{O}_{2}$.

\section{Scheme 9. Proposed pathways for the oxidation of $\alpha$-D styrene with $\mathrm{H}_{2} \mathrm{O}_{2}$ to generate acetophenone}

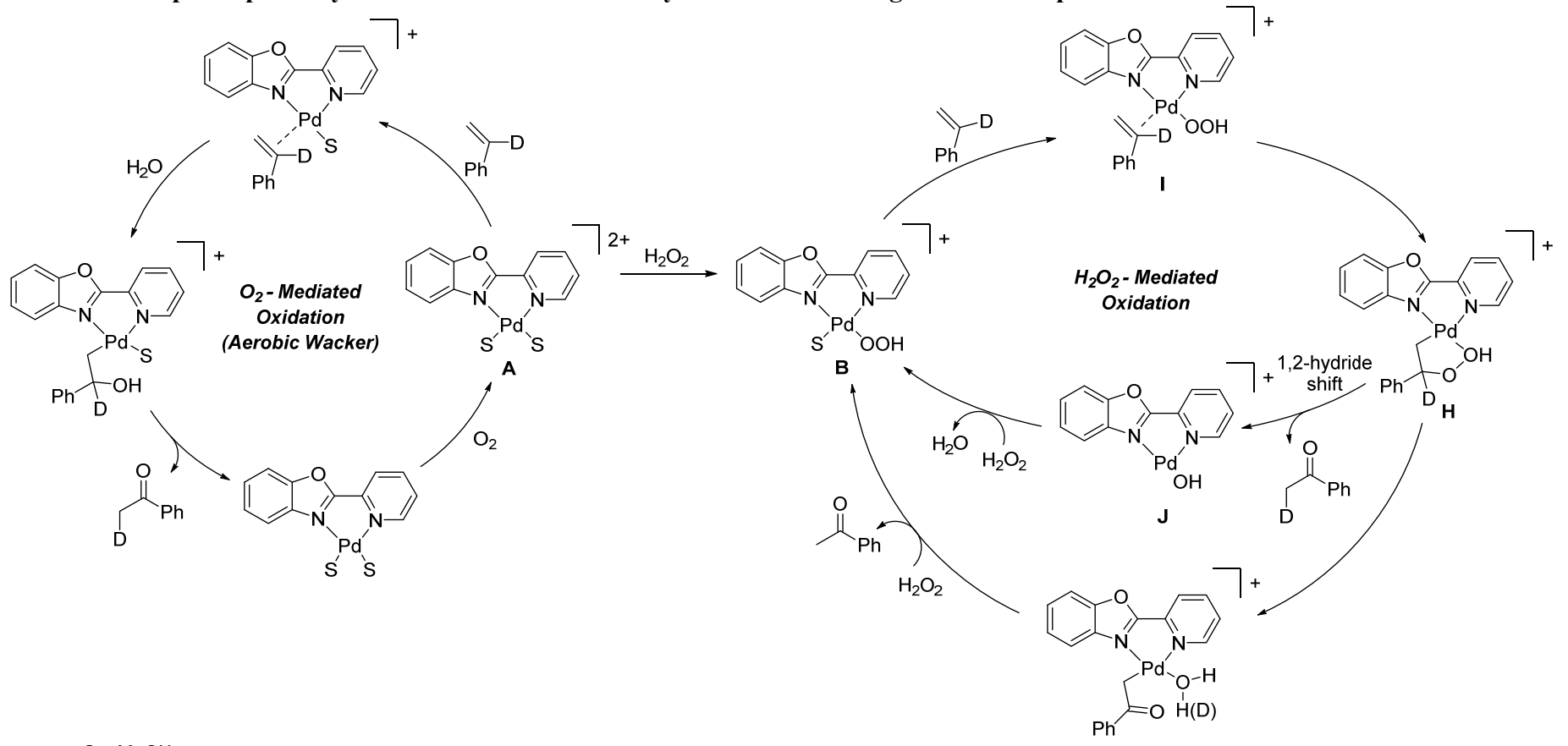

The reaction of intermediate $\mathbf{B}$ with styrene is proposed to generate the alkylperoxide intermediate $\mathbf{H}$ (Scheme 9); related intermediates have been proposed by both Mimoun ${ }^{44}$ and Sigman. ${ }^{44,51,54}$ This is consistent with linear kinetics plots obtained with varying styrene concentration. Although this intermediate was not observed directly by ESI under the typical reaction conditions, an ion at $439.0274 \mathrm{~m} / \mathrm{z}$ corresponding to the alkylhydroperoxide $\left.\left[(\mathrm{PBO}) \mathrm{PdCH}_{2} \mathrm{CH}(\mathrm{OOH}) \mathrm{Ph}\right)\right]^{+},[\mathbf{D}]^{+}$, was observed in the oxidation of styrene with $\mathrm{H}_{2} \mathrm{O}_{2}$ in presence of 1,4-cyclohexadiene. Moreover, when the oxidation of styrene was carried out with THBP as the terminal oxidant, ions corresponding to the alkylperoxide $\left.\left[(\mathrm{L}) \mathrm{Pd}-\mathrm{CH}_{2} \mathrm{CH}(\mathrm{OOtBu}) \mathrm{Ph}\right)\right]^{+}$were observed with Pd complexes ligated by both the Quinox and PBO. Collision-induced dissociation (CID) performed on this intermediate $\mathbf{H}$ shows that the structure of this intermediate is indeed the Pdalkylperoxide rather than simply the styrene-bound $\mathrm{Pd}-\mathrm{OOH}$ species $\mathbf{I}$.

The deuterium labeling studies strongly imply that the oxidation of styrene with $\mathrm{H}_{2} \mathrm{O}_{2}$ generates acetophenone by at least three competitive pathways (Scheme 9). Control experiments (Scheme 2) indicate that, in the absence of $\mathrm{H}_{2} \mathrm{O}_{2}$, acetophenone is formed in $24 \%$ yield after 24 hours by an aerobic Wacker reaction mediated by $\mathrm{O}_{2}$ and $\mathrm{H}_{2} \mathrm{O} .{ }^{47,76-78}$ The degree to which the aerobic Wacker competes with the $\mathrm{H}_{2} \mathrm{O}_{2}$-mediated oxidation is not clear, but the fact that $74 \%$ of the acetophenone is ${ }^{18} \mathrm{O}$ labeled when styrene is oxidized with $\mathrm{H}_{2}{ }^{18} \mathrm{O}_{2}$ (Scheme 4c) suggests that some of the acetophenone may be generated by the aerobic Wacker pathway as the water present is ${ }^{16} \mathrm{O}$. However, the ${ }^{16} \mathrm{O}$-labeled acetophenone could also come from an oxygenexchange between the ${ }^{18} \mathrm{O}$-labeled acetophenone and the $\mathrm{H}_{2}{ }^{16} \mathrm{O} .{ }^{79}$

For the $\mathrm{H}_{2} \mathrm{O}_{2}$-mediated oxidation, the labeling and mass spectrometry data imply two additional pathways: one that generates acetophenone by a 1,2-hydride shift from the Pd-alkylhydroperoxide, ${ }^{44,51,54}$ and another pathway that generates acetophenone by the protonolysis of the novel Pd enolate intermediate. Mimoun and Sigman had previously proposed a related 1,2-hydride shift to account for the formation of $\mathrm{d}_{1}$-acetophenone from the oxidation of $\alpha$-D styrene with TBHP. That approx. 30\% of $\mathrm{d}_{1}$-acetophenone is observed in the oxidation of $\alpha-\mathrm{D}$ styrene with $\mathrm{H}_{2} \mathrm{O}_{2}$ with $\mathbf{A}$ is consistent with a 1,2-hydride shift mechanism. However, some fraction of the $\mathrm{d}_{1}$-acetophenone could come from the competitive background aerobic Wacker mechanism.

The observation that a significant percentage (approx. 70\%) of the acetophenone generated from $\alpha$-D styrene is unlabeled 
and that a similar percentage (approx. 67\%) of styrene is deuteriated upon oxidation by $\mathrm{D}_{2} \mathrm{O}_{2}$ suggests that another competitive pathway must exist for the formation of acetophenone. We propose that this pathway involves the Pd C-bound enolate. The ESI-MS data reveals that ions corresponding to the Pd enolate $\mathbf{C}$ are among the most abundant ions observed, and the independent synthesis of an analogous compound with a 1,10-phenanthroline ligand is consistent with its formulation as a carbonbound enolate. ${ }^{63,80}$

When the oxidation of $\alpha$-D-styrene was monitored by ESIMS, the ion corresponding to the enolate $\mathbf{C}$ contained no deuterium, which is consistent with the observation that approx. $70 \%$ of the acetophenone generated from $\alpha$-D styrene contains no deuterium. When unlabeled styrene is oxidized with $\mathrm{D}_{2} \mathrm{O}_{2}$, the ion corresponding to the enolate $\mathbf{C}$ likewise contains no deuterium, although approx. $67 \%$ of the resulting acetophenone contains one deuterium. This latter observation could be explained by the protonolysis of the enolate by $\mathrm{D}_{2} \mathrm{O}_{2}$ (Scheme 9). The lack of an observable KIE for the oxidation of $\alpha$-D-styrene/styrene is consistent with the loss of the deuterium label prior to Pd-enolate decomposition.

Scheme 10: Two potential mechanisms for Pd-enolate formation from a Pd-alkylperoxide

(a) Deprotonation

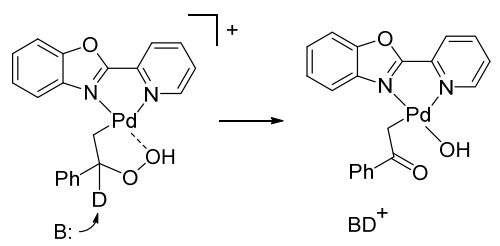

(b) Radical Homolysis

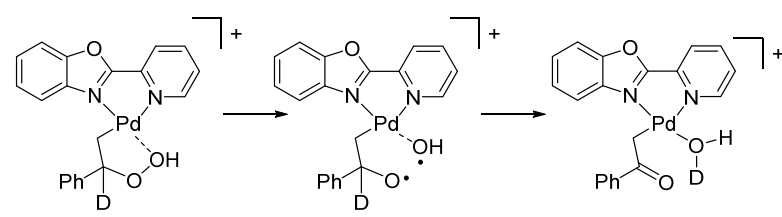

The proposed rearrangement the Pd-alkylhydroperoxide to the Pd enolate is precedented in the chemistry of alkylperoxides. ${ }^{81-83}$ Alkylperoxides bearing $\alpha$-hydrogen atoms are known to cleave to ketones by the Kornblum-DeLaMare rearrangement; ${ }^{81-83}$ both heterolytic ${ }^{82-83}$ and homolytic ${ }^{84}$ mechanisms for this rearrangement are precedented. Shown in Scheme 10 are two possible mechanisms for the formation of the Pd enolate from the Pd alkylhydroperoxide intermediate: one involving deprotonation facilitated by the coordination of the hydroperoxide to the cationic $\mathrm{Pd}$ center ${ }^{81-83}$ and another involving hydrogen-atom abstraction of the $\alpha-\mathrm{H}(\mathrm{D})$ and homolysis of the $\mathrm{O}-\mathrm{O}$ bond. ${ }^{84}$ Although either of these processes could account for the loss of the deuterium label when using $\alpha$-D-styrene as a substrate (Scheme $4 \mathrm{~b}$ ), our data to date do not allow us to distinguish between these two possibilities.

The observation of a Pd enolate in these $\mathrm{H}_{2} \mathrm{O}_{2}$-mediated oxidations was unexpected, as such species are rarely invoked in the oxidation of olefins by Pd. While we were unable to prepare this species independently with the PBO ligand, the isotope-labeling and ESI data provide compelling, if indirect, support for the intermediacy of carbon-bound $\mathrm{Pd}$ enolates in the $\mathrm{H}_{2} \mathrm{O}_{2}$-mediated oxidation of styrene with $\left[(\mathrm{PBO}) \mathrm{Pd}(\mathrm{NCMe})_{2}\right][\mathrm{OTf}]_{2}, \mathbf{A}$, and therefore provide new insights on oxidation mechanisms of olefins with peroxides.

While Pd-enolate intermediates were also observed in the oxidation of styrenes with the alkylperoxide TBHP using either $\left[(\mathrm{PBO}) \mathrm{Pd}(\mathrm{NCMe})_{2}\right][\mathrm{OTf}]_{2}$ (Scheme 8 ) or the (Quinox) $\mathrm{PdCl}_{2}$ system $^{54}$ (Scheme 7), the observation that $98 \%$ of the acetophenone was deuteriated with $\alpha$-D styrene implies that the enolate pathway is only a minor contributor when TBHP is used as the oxidant, irrespective of the diimine ligand. These results suggest that the different reactivities between the two peroxide oxidants can be rationalized by the different reactivities of the $\mathrm{Pd}$ alkylperoxide intermediates $\left.\left[(\mathrm{L}) \mathrm{Pd}-\mathrm{CH}_{2} \mathrm{CH}(\mathrm{OOR}) \mathrm{Ph}\right)\right]^{+}(\mathrm{R}=$ tBu vs. H).

\section{CONCLUSIONS}

In summary, a new mechanism involving Pd enolate intermediates is proposed for the oxidation of styrenes with $\mathrm{H}_{2} \mathrm{O}_{2}$ and catalysts derived from the cationic complex $\left[(\mathrm{PBO}) \mathrm{Pd}\left(\mathrm{NCMe}_{2}\right] \mathrm{OTf}_{2}\right.$. Kinetic investigations, isotope labeling studies and in-situ high-resolution mass spectrometry provide evidence for a mechanism involving the initial formation of a Pd hydroperoxide intermediate. This species reacts with styrene to generate a Pd-alkylhydroperoxide that liberates acetophenone by at least two competitive processes, one of which involves an unusual palladium enolate intermediate. Mechanistic and labeling studies indicate that oxidation pathways involving these novel palladium enolate intermediates are competitive with 1,2-hydride migration pathways with $\mathrm{H}_{2} \mathrm{O}_{2}$, whereas with t-butyl hydroperoxide, the 1,2-hydride mechanism dominates.

\section{ASSOCIATED CONTENT}

Supporting Information. Detailed kinetic procedure, data, and analysis, syntheses and NMR spectra, experimental ESI-MS spectra and computed ESI-MS for comparison. This material is available free of charge via the Internet at http://pubs.acs.org.

\section{AUTHOR INFORMATION}

\section{Corresponding Authors}

*waymouth@stanford.edu and m.j.muldoon@qub.ac.uk

\section{Author Contributions}

$\S$ These authors contributed equally.

\section{Funding Sources}

We acknowledge support from the Department of Energy (Grant DE-SC0005430, RMW), the Air Force Office of Scientific Research (Grant FA-9550-16-1-0113, RNZ), the Department of Employment and Learning (DEL), Northern Ireland and Queen's University Ionic Liquids Laboratories (MJM and LMD).

\section{ACKNOWLEDGMENT}

KLW acknowledges the Center for Molecular Analysis and Design (CMAD, Stanford) for a fellowship and the National Science Foundation Graduate Research Fellowship Program for support (GRFP). KLW would like to thank Erik Jansson for help with 
theta capillary experiments. LMD would like to thank the US-UK Fulbright Commission for a fellowship.

\section{REFERENCES}

1. Cornell, C. N.; Sigman, M. S., Inorg. Chem. 2007, 46 (6), 1903-1909.

2. Baiju, T. V.; Gravel, E.; Doris, E.; Namboothiri, I. N. N., Tetrahedron Lett. 2016, 57 (36), 3993-4000.

3. Mann, S. E.; Benhamou, L.; Sheppard, T. D., SynthesisStuttgart 2015, 47 (20), 3079-3117.

4. Jira, R., Angew. Chem. Int. Ed. 2009, 48 (48), 9034-9037.

5. Clement, W. H.; Selwitz, C. M., J. Org. Chem. 1964, 29 (1), 241-243.

6. Tsuji, J. N., H,; Hisao Nemoto, H., Organic Syntheses 1984, $9(62)$

7. Ogawa, H.; Fujinami, H.; Taya, K.; Teratani, S., J. Chem. Soc., Chem. Commun. 1981, (24), 1274-1275.

8. Davison, S. F.; Mann, B. E.; Maitlis, P. M., J. Chem. Soc., Dalton Trans. 1984, (6), 1223-1228.

9. Haruo, O.; Hideharu, F.; Kazuo, T.; Shousuke, T., Bull. Chem. Soc. Jpn. 1984, 57 (7), 1908-1913.

10. Stobbekreemers, A. W.; Dielis, R. B.; Makkee, M.; Scholten, J. J. F., J. Catal. 1995, 154 (2), 175-186.

11. Nowinska, K.; Dudko, D.; Golon, R., Chem. Commun. 1996, (2), 277-279.

12. Kim, Y.; Kim, H.; Lee, J.; Sim, K.; Han, Y.; Paik, H., Appl. Catal., A 1997, 155 (1), 15-26.

13. Nowińska, K.; Dudko, D., Appl. Catal., A 1997, 159 (1), 7587.

14. Nowińska, K.; Dudko, D., React. Kinet. Catal. Lett. 1997, 61 (1), 187-192.

15. Nowinèska, K.; Sopa, M.; Dudko, D.; Mocna, M., Catal. Lett. 1997, 49 (1), 43-48.

16. Kishi, A.; Higashino, T.; Sakaguchi, S.; Ishii, Y., Tetrahedron Lett. 2000, 41 (1), 99-102.

17. Yokota, T.; Sakakura, A.; Tani, M.; Sakaguchi, S.; Ishii, Y., Tetrahedron Lett. 2002, 43 (49), 8887-8891.

18. Melgo, M. S.; Lindner, A.; Schuchardt, U., Appl. Catal., A 2004, 273 (1-2), 217-221.

19. Zhizhina, E. G.; Simonova, M. V.; Odyakov, V. F.; Matveev, K. I., Appl. Catal., A 2007, 319, 91-97.

20. Ettedgui, J.; Neumann, R., J. Am. Chem. Soc. 2009, 131 (1), 4-5.

21. Bäckvall, J.-E.; Hopkins, R. B.; Grennberg, H.; Mader, M.; Awasthi, A. K., J. Am. Chem. Soc. 1990, 112 (13), 5160-5166.

22. Piera, J.; Bäckvall, J.-E., Angew. Chem. Int. Ed. 2008, 47 (19), 3506-3523.

23. Zhang, G.; Xie, X.; Wang, Y.; Wen, X.; Zhao, Y.; Ding, C., Org. Biomol. Chem. 2013, 11 (18), 2947-2950.

24. Miller, D. G.; Wayner, D. D. M., J. Org. Chem. 1990, 55 (9), 2924-2927.

25. Fernandes, R. A.; Chaudhari, D. A., J. Org. Chem. 2014, 79 (12), 5787-5793.

26. Fernandes, R. A.; Bethi, V., Tetrahedron 2014, 70 (32), 4760-4767.

27. Kulkarni, M. G.; Shaikh, Y. B.; Borhade, A. S.; Chavhan, S. W.; Dhondge, A. P.; Gaikwad, D. D.; Desai, M. P.; Birhade, D. R.; Dhatrak, N. R., Tetrahedron Lett. 2013, 54 (19), 2293-2295.

28. Chaudhari, D. A.; Fernandes, R. A., J. Org. Chem. 2016, 81 (5), 2113-2121

29. Nishimura, T.; Kakiuchi, N.; Onoue, T.; Ohe, K.; Uemura, S., J. Chem. Soc., Perkin Trans. 1 2000, (12), 1915-1918.

30. Brink, G.-J. t.; Arends, I. W. C. E.; Papadogianakis, G.; Sheldon, R. A., Appl. Catal., A 2000, 194-195, 435-442.

31. Mitsudome, T.; Umetani, T.; Nosaka, N.; Mori, K.; Mizugaki, T.; Ebitani, K.; Kaneda, K., Angew. Chem. Int. Ed. 2006, 45 (3), 481-485.
32. Cornell, C. N.; Sigman, M. S., Org. Lett. 2006, 8 (18), $4117-$

4120 .

33. Naik, A.; Meina, L.; Zabel, M.; Reiser, O., Chem. Eur. J. 2010, 16 (5), 1624-1628.

34. Wang, Y.-F.; Gao, Y.-R.; Mao, S.; Zhang, Y.-L.; Guo, D.D.; Yan, Z.-L.; Guo, S.-H.; Wang, Y.-Q., Org. Lett. 2014, 16 (6), 16101613.

35. McDonald, R. I.; Liu, G.; Stahl, S. S., Chem. Rev. 2011, 111 (4), 2981-3019.

36. ten Brink, G.-J.; W. C. E. Arends, I.; Papadogianakis, G.; A. Sheldon, R., Chem. Commun. 1998, (21), 2359-2360.

37. Wang, J.-L.; He, L.-N.; Miao, C.-X.; Li, Y.-N., Green Chem. 2009, 11 (9), 1317-1320.

38. Bueno, A. C.; de Souza, Á. O.; Gusevskaya, E. V., Adv. Synth. Catal. 2009, 351 (14-15), 2491-2495.

39. Cao, Q.; Bailie, D. S.; Fu, R.; Muldoon, M. J., Green Chem. 2015, 17 (5), 2750-2757.

40. Noyori, R.; Aoki, M.; Sato, K., Chem. Commun. 2003, (16), 1977-1986.

41. Caron, S.; Dugger, R. W.; Ruggeri, S. G.; Ragan, J. A.; Ripin, D. H. B., Chem. Rev. 2006, 106 (7), 2943-2989.

42. Russo, V.; Tesser, R.; Santacesaria, E.; Di Serio, M., Ind. Eng. Chem. Res. 2013, 52 (3), 1168-1178.

43. Moiseev, L.; Vargaftik, M.; Syrkin, J., Dokl. Akad. Nauk 1960, 130 (4), 820-823.

44. Roussel, M.; Mimoun, H., J. Org. Chem. 1980, 45 (26), 5387-5390.

45. Tsuji, J.; Nagashima, H.; Hori, K., Chem. Lett. 1980, 9 (3), $257-260$

46. Anderson, B. J.; Keith, J. A.; Sigman, M. S., J. Am. Chem. Soc. 2010, 132 (34), 11872-11874.

47. Keith, J. A.; Henry, P. M., Angew. Chem. Int. Ed. 2009, 48 (48), 9038-9049.

48. Harakat, D.; Muzart, J.; Le Bras, J., RSC Advances 2012, 2 (7), 3094-3099.

49. Comas-Vives, A.; Stirling, A.; Lledós, A.; Ujaque, G., Chem. Eur. J. 2010, 16 (29), 8738-8747.

50. Mimoun, H.; Charpentier, R.; Mitschler, A.; Fischer, J.; Weiss, R., J. Am. Chem. Soc. 1980, 102 (3), 1047-1054.

51. Cornell, C. N.; Sigman, M. S., J. Am. Chem. Soc. 2005, 127 (9), 2796-2797.

52. Michel, B. W.; Camelio, A. M.; Cornell, C. N.; Sigman, M. S., J. Am. Chem. Soc. 2009, 131 (17), 6076-6077.

53. DeLuca, R. J.; Edwards, J. L.; Steffens, L. D.; Michel, B. W.; Qiao, X.; Zhu, C.; Cook, S. P.; Sigman, M. S., J. Org. Chem. 2013 78 (4), 1682-1686.

54. Michel, B. W.; Steffens, L. D.; Sigman, M. S., J. Am. Chem. Soc. 2011, 133 (21), 8317-8325.

55. Ingram, A. J.; Boeser, C. L.; Zare, R. N., Chem. Sci. 2016, 7 (1), $39-55$

56. Ingram, A. J.; Solis-Ibarra, D.; Zare, R. N.; Waymouth, R. M., Angew. Chem. 2014, 126 (22), 5754-5758.

57. Ingram, A. J.; Walker, K. L.; Zare, R. N.; Waymouth, R. M. J. Am. Chem. Soc. 2015, 137 (42), 13632-13646.

58. Hesketh, A. V.; Nowicki, S.; Baxter, K.; Stoddard, R. L.; McIndoe, J. S., Organometallics 2015, 34 (15), 3816-3819.

59. Jašíková, L.; Anania, M.; Hybelbauerová, S.; Roithová, J. J. Am. Chem. Soc. 2015, 137 (42), 13647-13657.

60. Perry, R. H.; Cooks, R. G.; Noll, R. J., Mass Spectrom. Rev. 2008, 27 (6), 661-699.

61. Theron, R.; Wu, Y.; Yunker, L. P. E.; Hesketh, A. V.; Pernik, I.; Weller, A. S.; McIndoe, J. S., ACS Catalysis 2016, 6 (10), 6911 6917.

62. Chung, K.; Banik, S. M.; De Crisci, A. G.; Pearson, D. M.; Blake, T. R.; Olsson, J. V.; Ingram, A. J.; Zare, R. N.; Waymouth, R. M., J. Am. Chem. Soc. 2013, 135 (20), 7593-7602.

63. Culkin, D. A.; Hartwig, J. F., J. Am. Chem. Soc. 2001, 123 (24), 5816-5817. 
64. Perry, R. H.; Splendore, M.; Chien, A.; Davis, N. K.; Zare, R. N., Angew. Chem. Int. Ed. 2011, 50 (1), 250-254.

65. Takáts, Z.; Wiseman, J. M.; Gologan, B.; Cooks, R. G., Science 2004, 306 (5695), 471-473.

66. Mortensen, D. N.; Williams, E. R., Anal. Chem. 2014, 86 (18), 9315-9321.

67. Mortensen, D. N.; Williams, E. R., J. Am. Chem. Soc. 2016, 138 (10), 3453-3460.

68. Jansson, E. T.; Lai, Y. H.; Santiago, J. G.; Zare, R. N., J. Am. Chem. Soc. 2017, 139 (20), 6851-6854

69. Xia, X.; Gao, X.; Xu, J.; Hu, C.; Peng, X., Synlett 2017, 28 (05), 607-610

70. Chiappe, C.; Sanzone, A.; Dyson, P. J., Green Chem. 2011, 13 (6), 1437-1441.

71. Scheuermann, M. L.; Goldberg, K. I., Chem. Eur. J. 2014, 20 (45), 14556-14568

72. Konnick, M. M.; Gandhi, B. A.; Guzei, I. A.; Stahl, S. S., Angew. Chem., Int. Ed. 2006, 45 (18), 2904-7.

73. Decharin, N.; Popp, B. V.; Stahl, S. S., J. Am. Chem. Soc. 2011, 133 (34), 13268-13271.

74. Konnick, M. M.; Decharin, N.; Popp, B. V.; Stahl, S. S., Chem. Sci. 2011, 2 (2), 326-330.
75. Konnick, M. M.; Guzei, I. A.; Stahl, S. S., J. Am. Chem. Soc. 2004, 126 (33), 10212-10213.

76. Keith, J. A.; Nielsen, R. J.; Oxgaard, J.; Goddard, W. A., J. Am. Chem. Soc. 2007, 129 (41), 12342-12343.

77. Bäckvall, J.-E.; Akermark, B.; Ljunggren, S. O., J. Chem. Soc., Chem. Commun. 1977, (8), 264-265.

78. Stille, J. K.; Divakaruni, R., J. Organomet. Chem. 1979, 169 (2), 239-248

79. Byrn, M.; Calvin, M., J. Am. Chem. Soc. 1966, 88 (9), 19161922.

80. Hamann, B. C.; Hartwig, J. F., J. Am. Chem. Soc. 1997, 119 (50), 12382-12383.

81. Yaremenko, I. A.; Vil, V. A.; Demchuk, D. V.; Terent'ev, A. O., Beilstein J. Org. Chem. 2016, 12, 1647-1748.

82. Kornblum, N.; Delamare, H. E., J. Am. Chem. Soc. 1951, 73 (2), 880-881.

83. Kelly, D. R.; Bansal, H.; Morgan, J. J. G., Tetrahedron Lett. 2002, 43 (51), 9331-9333.

84. Dixon, B. G.; Schuster, G. B., J. Am. Chem. Soc. 1979, 101 (11), 3116-3118. 


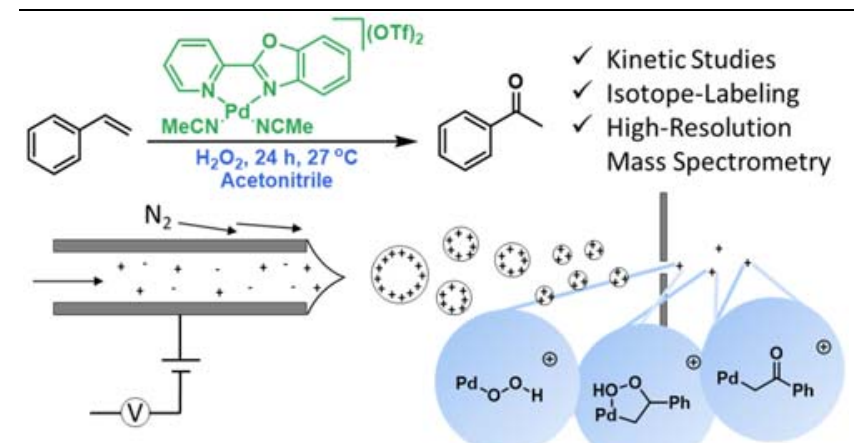

